\title{
Prednisone Increases the Number of Insulin Receptors in Erythrocytes from Children
}

\author{
BERTRAND CANIVET, ${ }^{(40)}$ CLAUDINE POUSTIS-DELPONT, ROGER MARIANI, AND \\ PIERRE FREYCHET \\ Department of Experimental Medicine, INSERM U 145, Faculté de Médecine, Chemin de Vallombrose, \\ 06034 Nice Cédex, France [B.C., P.F.] and Department of Pediatrics, Hôpital de Cimiez, 4, avenue Reine Victoria, \\ 06031 Nice Cédex, France [C.P.-D., R.M.]
}

\begin{abstract}
Summary
Erythrocyte insulin receptors were studied in nine children treated with prednisone $(2 \mathrm{mg} / \mathrm{kg}$ body weight/day) for various diseases. Two children were treated for 7 days and the other seven for 14 days. Fasting blood glucose rose slightly but significantly $(P<0.025)$ during prednisone administration; this rise was accompanied by a 2-fold increase in fasting plasma insulin levels (from $11.6 \pm 4.5$ before to $20.8 \pm 12 \mu \mathrm{U} / \mathrm{ml}$ after 7 days of treatment, means + S.D., $P<0.05$ ). This insulin resistant state was maintained throughout prednisone therapy and was reversed 5 days after cessation of treatment. The binding of $\left[{ }^{125} 1\right]$ insulin at tracer concentration $(0.1 \mathrm{ng} / \mathrm{ml})$ to erythrocytes, expressed as $\%$ of $\left[{ }^{125} \mathrm{I}\right]$ insulin specifically bound to $4.4 \times 10^{9}$ cells, rose from $10.7+1.7 \%$ before to $16.1+4.0 \%$ after 7 days of prednisone therapy (means + S.D., $P<0.025$ ). This rise was accounted for by a 2 -fold increase in the number of receptors per cell (from $54+11$ before to $97+25$ after 7 days of treatment, means + S.D., $P<0.05$ ), with no detectable change in receptor affinity. This alteration in the number of erythrocyte receptors was observed throughout the period of prednisone administration, and was reversed 5 days after prednisone withdrawal. The development of insulin resistance despite the increase in the number of insulin receptors suggests that prednisone alters the cellular mechanism(s) of insulin action at a step (or steps) distal to the insulin receptor.
\end{abstract}

\section{Abbreviations}

$B / F$, bound to free

FBG, fasting blood glucose

$\overline{\mathbf{K}}$, affinity at low receptor occupancy

Ro, total receptor number

Carbohydrate intolerance is a well established consequence of glucocorticoid excess, that can occur spontaneously $(27,35,36)$ or in response to exogenous glucocorticoid administration in man (8, $26)$ or in animals (1). This glucocorticoid-induced glucose intolerance is related to an insulin-resistant state which is manifested by a varying degree of hyperglycemia in the face of hyperinsulinemia $(26,27,34,36)$. It was first thought that the effect of glucocorticoids could be accounted for mainly by increased gluconeogenesis (22). In fact, glucocorticoids seem both to increase hepatic glucose output and to inhibit peripheral glucose utilization in animals $(2,30)$ and in man (33).

The possible role of a glucocorticoid-induced alteration of the insulin receptor has recently been examined. Animal and in vitro studies have led to conflicting results: the effects of glucocorticoids on insulin binding to its receptor were variable, depending on the type of glucocorticoid tested, the cellular model used and the duration of its exposure to steroid $(7,10,21,23,31,32)$. The investigation of insulin binding after glucocorticoid administration to human subjects has also provided ambiguous results $(3,11,15$, $29,38)$. Prednisone administration to normal adult subjects has been shown to increase insulin binding, $(3,29)$ to have no effect, (15) or to decrease insulin binding (38). On the other hand, dexamethasone administration is usually accompanied by decreased insulin binding $(11,38)$. Such studies have not been reported in children. Indeed, monocytes or adipocytes are not easily accessible for repeated measurements of insulin receptors in children. The method used to measure insulin binding to erythrocyte receptors (20) has been improved (19) and can easily be used in children, even when repeated measures are needed because small amounts of blood are required (24). In the present study we have investigated the binding of insulin to erythrocytes from children treated with prednisone.

\section{MATERIALS AND METHODS}

Patients and protocols. Nine hospitalized prepubertal children, six girls and three boys aged $1.5-8$ years (mean 3.1), were investigated. All had normal weight for height. None was diabetic nor had a family history of diabetes. They were submitted to prednisone treatment $\left(2 \mathrm{mg} \cdot \mathrm{kg}^{-1} \cdot \mathrm{day}^{-1}\right)$ following two different therapeutic regimes. Two children were treated for 7 days; prednisone was then decreased and stopped within 2 days. Another group consisted of seven children who were treated for 14 days; the dose was then gradually decreased during the next 9 days. Prednisone was administered for the treatment of the following diseases: thrombocytopenia (three cases), pulmonary diseases (four cases) and neurologic disorders (two cases).

Patients were studied after they fasted overnight. A blood sample $(5 \mathrm{ml})$ was collected from all subjects before starting prednisone treatment. In the two children treated for 7 days, fasting blood samples were collected again on day 7 and on day 14. In the other seven children (treated for 14 days), fasting blood samples were collected at day $7,14,21$, and 28 .

The data obtained five days after prednisone withdrawal (i.e., on day 14 for the former two children and on day 28 for the other seven children) were combined and are referred to as "after therapy" data. Informed consent for the drawing of $5 \mathrm{ml}$ of blood was obtained from the parents.

Insulin binding studies. Whole blood $(5 \mathrm{ml})$ was collected into heparinized tubes. Erythrocytes were separated from other blood cells by a modification of the method of Böyum, (6) as reported by Gambhir et al. (19).

Insulin was iodinated to a specific activity of $250-300 \mu \mathrm{Ci} / \mu \mathrm{g}$, using a modification referred to as the second modification in ref (18) of the chloramine-T method. The $\left[{ }^{125} I\right]$ iodoinsulin was purified on Sephadex G-50 column.

For binding assays, the incubation of red blood cells with insulin and the separation of insulin bound to erythyrocytes from free insulin was performed as described by Gambhir et al. (19). Competition curves were obtained by incubating $\left[{ }^{125} \mathrm{I}\right]$ insulin $(0.1$ $\mathrm{ng} / \mathrm{ml}$ ) with erythrocytes for $210 \mathrm{~min}$ at $15^{\circ} \mathrm{C}$ in the absence or presence of various concentrations of unlabeled insulin (11 concentration points ranging from $0.5-10,000 \mathrm{ng} / \mathrm{ml}$ ). Each concentration point was run in duplicate; tracer insulin binding, i.e., the 
binding of $\left[{ }^{125} \mathrm{C}\right]$ insulin alone at $0.1 \mathrm{ng} / \mathrm{ml}$ (referred to as Bo), was run in quadruplicate. Because insulin binding is linearly related to erythrocyte concentration over a range of $0.2-5 \times 10^{9}$ cells $/ \mathrm{ml}$ (data not shown; and ref. 24), we used final erythrocyte concentrations of $1.5-3 \times 10^{9}$ cells $/ \mathrm{ml}$, which enabled us to perform complete competition curves with the erythrocytes from $5 \mathrm{ml}$ of whole blood. Results were corrected to a final concentration of $4.4 \times 10^{9}$ cells $/ \mathrm{ml}$ for purposes of comparison.

Degradation of insulin occurring during the binding assay was estimated by $10 \%$ trichloroacetic acid precipitation of $\left[{ }^{125} \mathrm{I}\right]$ insulin in the supernatant buffer (free insulin) at the end of the incubation this degradation was always less than $8 \%$ of the total $\left[{ }^{125} \mathrm{I}\right]$ insulin added originally to the incubation mixture.

Analysis of binding data. All data have been expressed as specific binding of insulin to erythrocytes after subtraction of nonspecific binding. This nonspecific component was determined by a linear regression analysis of the nonsaturable component of binding, using the four highest insulin concentrations tested (ranging from $500-10,000 \mathrm{ng} / \mathrm{ml}$ ) as previously described (16). Nonspecific binding ranged from $6-21 \%$ of total binding. The concentration of insulin necessary to inhibit $50 \%$ of the binding of $\left[{ }^{125} \mathrm{r}\right]$ insulin (referred to as IC50) was determined from competition curves. The total number of binding sites per cell (referred to as Ro) and the affinity for insulin at low insulin concentration $(\overline{\mathrm{K}} \mathrm{e})$ were derived by Scatchard analysis (37) of the competition curves according to De Meyts and Roth (9).

Analytical procedures. Blood cell counts, hemoglobin concentration, and hematocrit were determined in a Coulter counter; a reticulocyte count was performed on each sample. Blood glucose was measured by the glucose oxidase method. Plasma immunoreactive insulin was assayed by the double antibody method (28).

Statistical analysis. Student's $t$ test for paired data was used to compare results obtained during and after prednisone therapy with those observed before treatment.

\section{RESULTS}

Hematologic and biochemical data are presented in Table 1. Mean red cell count, hemoglobin concentration, and hematocrit were normal and did not vary thoughout the study. Reticulocyte counts (\% of total red cells) were not significantly affected by prednisone administration. FBG was found to be slightly but significantly increased on days 7 and 14 of prednisone therapy; on day 21 (corresponding to a decreased dose) FBG was not statistically different, although still slightly elevated from the pretherapeutic value. Five days after prednisone withdrawal, FBG had returned to the pretherapeutic value. Prednisone treatment resulted in a marked (about 100\%) increase in fasting plasma insulin, which remained elevated throughout the period of administration of the drug. Plasma insulin returned promptly to the pretherapeutic level after the cessation of prednisone administration (Table 1).

Insulin binding to erythrocytes was altered during the administration of prednisone. The binding at low insulin concentration $\left(0.1 \mathrm{ng} / \mathrm{ml} \mathrm{[}{ }^{125} \mathrm{I}\right]$ insulin, referred to as Bo) was increased by about $50 \%$ over the pretherapeutic value (Table $2 ;$ Fig. 1 ). This increase was observed at day 7 of therapy and was maintained throughout the administration of the drug; Bo returned to the pretherapeutic value shortly (5 days) after cessation of prednisone treatment (Table 2). Competition curves of $\left[{ }^{125} \mathrm{I}\right]$ insulin binding by unlabeled insulin with erythrocytes obtained before and after 7 days of prednisone administration are depicted in Figure 1. Insulin binding was increased over a broad range of insulin concentrations in cells from prednisone-treated patients. The concentrations of unlabeled insulin necessary to inhibit $50 \%$ of $\left[{ }^{125} \mathrm{I}\right]$ insulin binding (referred to as IC50) did not vary significantly throughout the study (Table 2). Scatchard analysis of these data (before and during prednisone administration) yielded parallel curvilinear plots with different intercepts on the abscissa (Fig. 2), indicating that in erythrocytes from prednisone-treated patients the increase in insulin binding was accounted for by an increase in total receptor number, rather than by a change in receptor affinity. Accordingly, the calculation from Scatchard plots of total receptor number (Ro) and of the affinity at low receptor occupancy $(\overline{\mathrm{K}} \mathrm{e})$ (9) revealed that Ro was increased in erythrocytes from prednisone-treated patients by $60-90 \%$ over the pretherapeutic value throughout the period of drug administration. No significant change was observed for $\overline{\mathrm{K} e}$ values (Table 2 ). Upon cessation of prednisone treatment, Ro returned to a value that was not statistically different from that observed before therapy (Table 2).

\section{DISCUSSION}

The present study has shown that prednisone therapy in children results in a $60-90 \%$ increase in insulin binding to erythrocytes, owing to an increase in the number of insulin receptors.

Table 1. Hematologic and biochemical data before, during and after prednisone treatment ${ }^{1}$

\begin{tabular}{lccccc}
\hline & $\begin{array}{c}\text { Before } \\
(n=9)\end{array}$ & $\begin{array}{c}\text { Day 7 } \\
(n=9)\end{array}$ & $\begin{array}{c}\text { Day 14 } \\
(n=7)\end{array}$ & $\begin{array}{c}\text { Day 21 } \\
(n=7)\end{array}$ & $\begin{array}{c}\text { After } \\
(n=9)\end{array}$ \\
\hline Red cell count $\left(10^{9} / \mathrm{ml}\right)$ & $4.5 \pm 0.2$ & $4.3 \pm 0.3$ & $4.5 \pm 0.4$ & $4.5 \pm 0.3$ & $4.3 \pm 0.2$ \\
Hemoglobin concentration (mmole/liter) & $7.6 \pm 0.6$ & $7.4 \pm 0.8$ & $7.9 \pm 0.7$ & $7.6 \pm 1.0$ & $7.4 \pm 0.6$ \\
Hematocrit $(\%)$ & $36.8 \pm 2.7$ & $35.8 \pm 3.9$ & $38.2 \pm 1.8$ & $37.3 \pm 2.0$ & $36.8 \pm 2.6$ \\
Reticulocytes $(\%$ of red cells) & $1.9 \pm 1.2$ & $1.9 \pm 1.2$ & $2.3 \pm 1.5$ & $2.1 \pm 1.0$ & $1.5 \pm 0.7$ \\
Fasting blood glucose $(\mathrm{mmole} /$ liter) & $3.8 \pm 0.7$ & $4.5 \pm 0.8^{* *}$ & $4.6 \pm 0.6^{* *}$ & $4.1 \pm 0.8$ & $3.6 \pm 0.5$ \\
Fasting plasma insulin $(\mu \mathrm{U} / \mathrm{ml})$ & $11.6 \pm 4.5$ & $20.8 \pm 12^{*}$ & $22.1 \pm 13.5^{*}$ & $22.1 \pm 14.6^{*}$ & $10.0 \pm 5.8$ \\
\hline
\end{tabular}

${ }^{1}$ Each value is the mean \pm S.D. The number of subjects $(n)$ is given at the top of each column. Differences between data obtained during and before treatment are significant where indicated with ${ }^{*} P<0.05$; and ${ }^{* *} P<0.025$.

Table 2. Insulin binding data with erythrocytes from children before, during and after prednisone treatment

\begin{tabular}{lccccc}
\hline & $\begin{array}{c}\text { Before } \\
(n=9)\end{array}$ & $\begin{array}{c}\text { Day } 7 \\
(n=9)\end{array}$ & $\begin{array}{c}\text { Day 14 } \\
(n=7)\end{array}$ & $\begin{array}{c}\text { Day 21 } \\
(n=7)\end{array}$ & $\begin{array}{c}\text { After } \\
(n=9)\end{array}$ \\
\hline Bo $(\%)$ & $10.7 \pm 1.7$ & $16.1 \pm 4.0^{* *}$ & $15.8 \pm 3.8^{*}$ & $15.5 \pm 2.9^{* *}$ & $11.3 \pm 1.4$ \\
IC 50 $(\mathrm{ng} / \mathrm{ml})$ & $6.6 \pm 2.1$ & $6.8 \pm 2.4$ & $6.9 \pm 2.6$ & $6.6 \pm 2.0$ & $6.5 \pm 2.5$ \\
$\operatorname{Ro}($ sites per cell) & $54 \pm 11$ & $97 \pm 25^{*}$ & $101 \pm 25^{*}$ & $87 \pm 19^{*}$ & $63 \pm 12$ \\
$\operatorname{Re}\left(10^{8} \mathrm{M}^{-1}\right)$ & $2.7 \pm 0.5$ & $2.8 \pm 0.4$ & $2.8 \pm 0.6$ & $2.5 \pm 0.4$ & $2.4 \pm 0.4$ \\
\hline
\end{tabular}

${ }^{1}$ Each value is the mean \pm S.D. The number of subjects $(n)$ is given at the top of each column. Bo refers to the binding of $\left[{ }^{125} \mathrm{I}\right]$ insulin at the lowest ("tracer") concentration tested $(0.1 \mathrm{ng} / \mathrm{ml}$, i.e., $2.5 \mu \mathrm{U} / \mathrm{ml}$ or $16 \mathrm{pmole} /$ liter) and is expressed as \% of total hormone specifically bound. IC 50 represents the concentration of unlabeled insulin that inhibits $50 \%$ of $\left[{ }^{125} \mathrm{r}\right]$ insulin specific binding. Ro and $\overline{\mathrm{K}} \mathrm{e}$ correspond to the total number of sites/cell and the affinity at tracer $(0.1 \mathrm{ng} / \mathrm{ml})$ insulin concentration, respectively. Differences between data obtained during and before treatment are significant where indicated with ${ }^{*} P<0.05$ and ${ }^{* *} P<0.025$. 


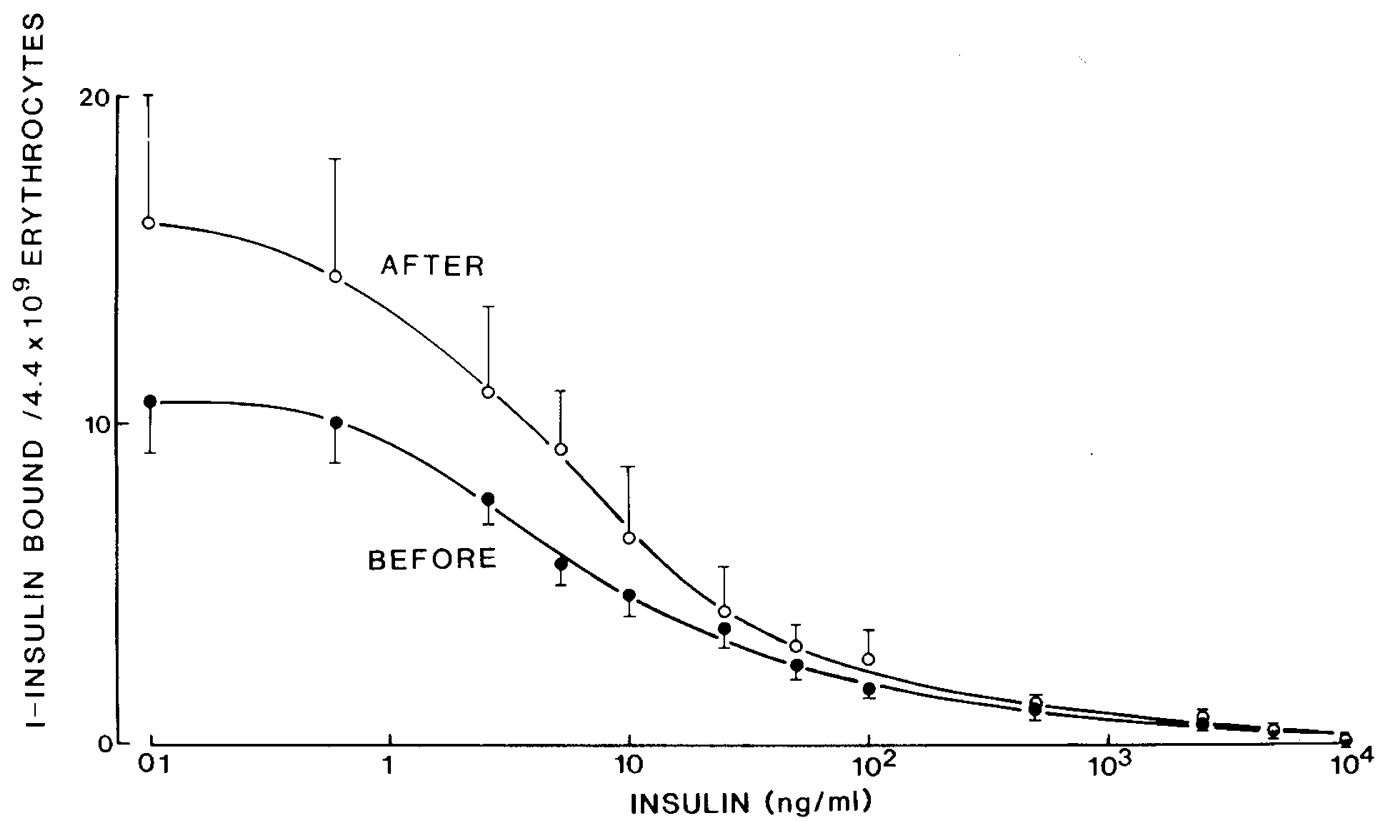

Fig. 1. Competition curves of $\left[{ }^{125} \mathrm{I}\right]$ insulin binding by unlabeled insulin with erythrocytes obtained before and after 7 days of prednisone treatment. The $\%$ of $\left[{ }^{125}\right.$ I] insulin specifically bound to $4.4 \times 10^{9}$ cells is plotted against total insulin concentration. Each point represents the mean + S.D. of individual data obtained from nine children, before the onset

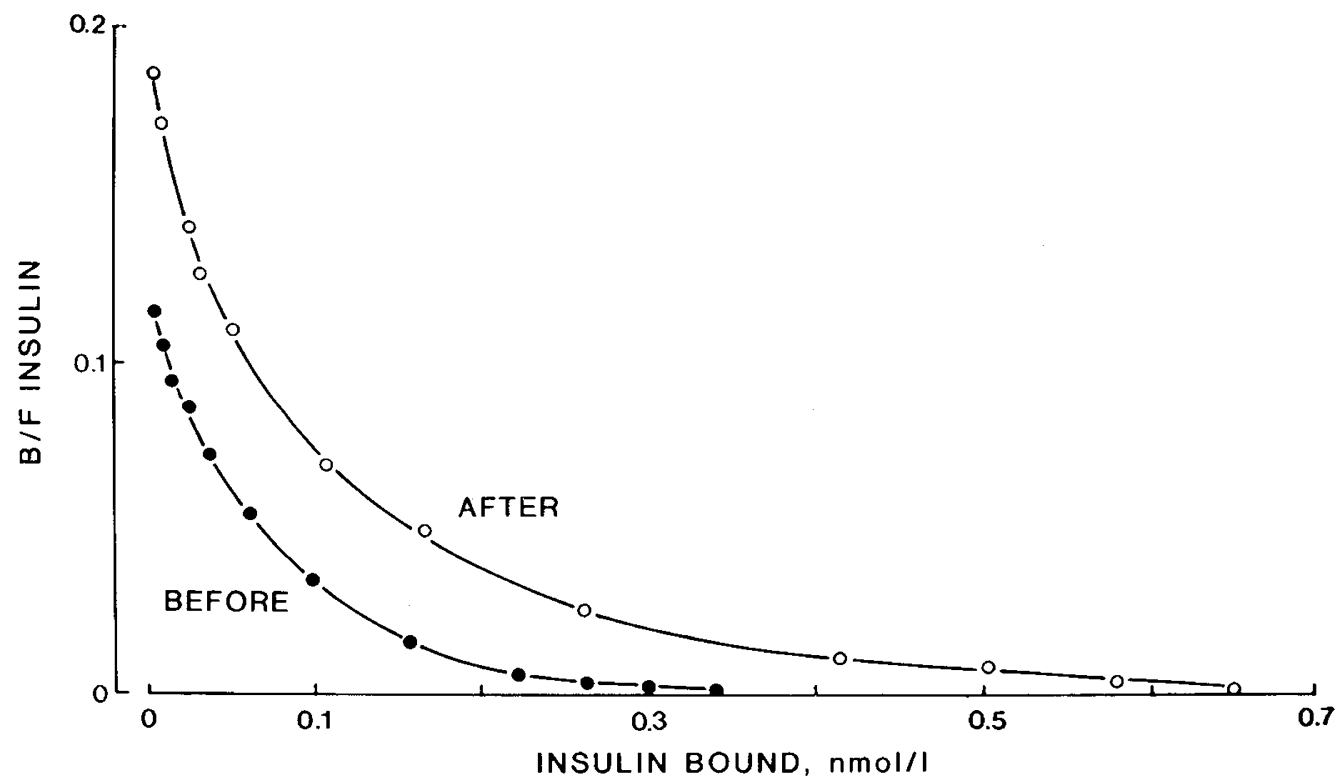

Fig. 2. Scatchard plots of insulin binding to erythrocytes obtained from nine children before ( $(\mathrm{O}-\mathrm{O})$. Plots were derived from data shown in Figure 1. The bound to free (B/F) insulin ratio is plotted against the corresponding concentration of bound hormone. Total receptor number $(\mathrm{Ro})$ was determined from the abscissa intercept. The affinity at low receptor occupancy $(\overline{\mathrm{K}} \mathrm{e})$ was obtained $(30)$ by dividing B/F by (Ro-B), with B representing bound insulin at the lowest concentration tested $(0.1 \mathrm{ng} / \mathrm{ml})$. Values of Ro and $\overline{\mathrm{K}} \mathrm{e}$ are listed in Table 2.

Because insulin binding is influenced by the age of erythrocytes $(12,14,25)$, care was taken to exclude anemic patients with reticulocytosis. Investigated subjects were all prepubertal because variations in insulin binding may also occur during the menstrual cycle (4). In our study, variations in the \% of reticulocytes were not significant, although a slight increase was observed at day 14 of prednisone administration (Table 1). Insulin binding was already enhanced at day 7 (Table 2), before the slight increase in reticulocytes; moreover, Muggeo et al. (29) have reported that in erythrocytes from normal adults given prednisone, insulin binding is increased irrespective of the mean age of the red cell population, as assessed by the creatine content of erythrocytes. Although we cannot totally exclude the possibility of an effect of prednisone on medullary red cell production, we may reasonably assume that the
60-90\% increase in insulin binding which we observed did not predominantly depend on this phenomenon.

In agreement with our results, an increase in the number of insulin receptors has been observed in monocytes from healthy adult subjects given prednisone (3). It has also been recently reported that insulin binding in erythrocytes from normal adults is increased after prednisone administration (29). In contrast, a decreased insulin binding (due to a decreased receptor affinity) has been observed in erythrocytes of normal adults after prednisone ingestion (38) whereas no change was reported in another study using monocytes (15). The apparent discrepancy between these results may stem from the duration of prednisone administration; thus, in the studies where no change (15), or a decrease (38), in insulin binding was reported, prednisone was administered 
for only 3 days (15), or even as a single dose (38). We, and Muggeo et al. (29), performed a more prolonged study over several weeks (present study) or months (29). This duration of prednisone administration may be necessary in order to observe an increase in the number of insulin receptors; however, such an increase was observed on monocytes within a few hours after prednisone intake (3).

In the present study, the development of a state of insulin resistance in prednisone-treated children is indicated by a 2 -fold increase in fasting plasma insulin levels with a concomitant slight increase in fasting blood glucose. Under the conditions of our study, this state of insulin resistance was transient, and was no longer detected within 5 days after cessation of therapy. A striking observation in the face of insulin resistance was the $60-90 \%$ increase in the number of insulin receptors, which we observed with erythrocytes from prednisone-treated patients. Insulin-resistant states have been shown to be accompanied by a decreased number (or affinity) of insulin receptors, although with some exceptions (for a review, see ref 5) including the present study. Accordingly, there usually exists an inverse relationship between insulin binding and fasting plasma insulin levels in hyperinsulinemic states (5), which was not found to be the case in the present study where insulin binding increased despite fasting hyperinsulinemia. In human and animal studies, other glucocorticoids such as cortisone and dexamethasone have been shown to cause insulin resistance by interfering at both receptor and postreceptor steps $(10,21)$. Insofar as insulin receptors on erythrocytes reflect the status of insulin receptors on major target tissues like muscle, liver, and fat, our results suggest that prednisone-induced insulin resistance results from postreceptor defects. It is not clear at present whether the insulin receptor status of erythrocytes mirrors that of target cells. Binding data obtained with erythrocytes are usually, although not consistently, in good agreement with those obtained with monocytes (13).

The mechanism(s) whereby prednisone enhances the number of insulin receptors is (are) presently unknown. In erythrocytes, prednisone may stimulate the biosynthesis of the receptor in immature red cells without altering the number of these cells, although such a mechanism is unlikely because Muggeo et al. (29) have reported that the increase in insulin receptor number occurs irrespective of the cell age. Alternatively, the drug may alter the intracellular traffic of the receptor by inhibiting its internalization (17), or by favoring its recycling to the cell membrane, or both; however, these processes have thus far not been demonstrated in red blood cells. Further studies will be required to elucidate this peculiar aspect of prednisone action and its consequences on the clinical and hormonal status of the patients treated by this agent.

\section{REFERENCES AND NOTES}

1. Bates, R. W. and Garrison, M. M.: Studies in $80 \%$ pancreatectomized rats of the synergistic interaction of growth hormone, ACTH and the glucocorticoids as diabetogenic agents. Endocrinology, 88: 1429 (1971).

2. Baxter, J. D. and Forsham, R. H.: Tissue effects of glucocorticoids. Am. J. Med., 53: 573 (1972)

3. Beck-Nielsen, H., De Pirro, R., and Pedersen, O.: Prednisone increases the number of insulin receptors on monocytes from normal subjects. J. Clin. Endocrinol. Metab. 50: 1 (1980)

4. Bertoli, A., De Pirro, R., Fusco, A., Greco, A. V., Magnatta, R., and Lauro, R.: Differences in insulin receptors between men and menstruating women and influence of sex hormones on insulin binding during the menstrual cycle. $\mathbf{J}$. Clin. Endocrinol. Metab., 50: 246 (1980).

5. Blecher, M. and Bar, R. S.: Receptor and Human Disease. pp. 77-94. (Williams and Wilkins, Baltimore, 1981).

6. Böyum, A.: A one-stage procedure for isolation of granulocytes and lymphocytes from human blood. General sedimentation properties of white blood cells in a $\mathrm{lg}$ gravity field. Scand. J. Clin. Lab. Invest., 21 (suppl 97): 51 (1968).

7. Cigolini, $M$ and Smith, U.: Human adipose tissue in culture. VIII. Studies on the insulin antagonistic effect of glucocorticoids. Metabolism, 28: 502 (1979).

8. Conn, J. W. and Fajans, S. S.: Influence of adrenal cortical steroids on carbohydrate metabolism in man. Metabolism, 5: 114 (1956).

9. De Meyts, P. and Roth, J.: Cooperativity in ligand binding: a new graphic analysis. Biochem. Biophys. Res. Commun., 66: 1118 (1975).
10. De Pirro, R., Green, A., Yung-Chin, M., and Olefsky, J. M.: Effects of prednisone and dexamethasone in vivo and in vitro: studies of insulin binding, deoxyglucose uptake and glucose oxidation in rat adipocytes. Diabetologia, 21: 149 (1981).

11. Di Pirro, R., Bertoli, A., Fusco, A., Testa, I., Greco, A. V., and Lauro, R.: Effect of Dexamethasone and cortisone on insulin receptors in normal human male. J. Clin. Endocrinol. Metab., 51: 503 (1980)

12. Dons, R. F., Corash, L. M., and Gorden, P.: The insulin receptor is an agedependent integral component of the human erythrocyte membrane. J. Biol. Chem. 256: 2982 (1981).

13. Dons, R. F. Ryan, J., Gorden, P., Waschlicht-Rodbard, H, and Roth, J. Erythrocyte and monocyte insulin binding in man: a comparative analysis in normal and disease states. Diabetes, 30: 896 (1981).

14. Eng., J., Lee, L., and Yalow, R. S.: Influence of the age of erythrocytes on their insulin receptors. Diabetes, 29: 164 (1980).

15. Fantus, I. G., Ryan, J., Hizuka, H., and Gorden, P.: The effect of glucocorticoids on the insulin receptor: an in vivo and in vitro study, J. Clin. Endocrinol. Metab., 52: 953 (1981).

16. Fehlmann, M., Morin, O., Kitabgi, P., and Freychet, P.: Insulin and glucagon receptors of isolated rat hepatocytes. Comparison between hormone binding and amino acid transport stimulation. Endocrinology, 109: 253 (1981).

17. Fehlmann, M., Carpentier, J. L., Le Cam, A., Thamm, P., Saunders, D., Brandenburg, D., Orci, L., and Freychet, P.: Biochemical and morphological evidence that the insulin receptor is internalized with insulin in hepatocytes. J. Cell. Biol., 93: 82 (1982).

18. Freychet, P.: Insulin receptors, In: Blecher M. (Ed) Methods in Receptor Research. Part 2, pp 385-428. (Marcel Dekker, New York, 1976).

19. Gambhir, K. K., Archer, J. A., and Bradley, C. J.: Characteristics of human erythrocyte insulin receptors. Diabetes, 27: 701 (1978)

20. Gavin, J. R. III, Roth, J. Jen, P., and Freychet, P.: Insulin receptors in human circulating cells and fibroblasts. Proc. Natl. Acad. Sci. USA, 69: 747 (1972).

21. Grunfeld, C., Baird, K., Van Obberghen, E., and Kahn, C. R.. Glucocorticoidinduced insulin resistance in vitro: evidence for both receptor and postreceptor defects. Endocrinology, 109: 1723 (1981).

22. Haynes Jr., R. C.: Studies on in vitro effect of glucocorticoids on gluconeogenesis. Endocrinology, 7l: 399 (1962).

23. Kahn, C. R., Goldfine, I. D., Neville, D. M., and De Meyts, P.: Alterations in insulin binding induced by changes in vivo in the levels of glucocorticoids and growth hormone. Endocrinology, 103: 1054 (1978).

24. Kappy, M. S. and Plotnick, L.: Studies of insulin binding in children using human erythrocytes in small amounts of blood. Diabetes, 28: 1001 (1979).

25. Kosmakos, F. C., Nagulesparan, M., and Bennett, P. H.: Insulin binding to erythrocytes: a negative correlation with red cell age. J. Clin. Endocrinol. Metab., 51: 46 (1980).

26. McKiddie, M. T., Jasami, M. K., Buchanan, K. D., Boyle, J. A., and Buchanan, W. W.: The relationship between glucose tolerance, plasma insulin and corticosteroid therapy in patients with rheumatoid arthritis. Metabolism, 17: 30 (1968).

27. Modigliani, E., Strauch, G., Luton, J. P., and Bricaire, H.: Effect of glucose and arginine on insulin secretion in Cushing's syndrome. Diabetologia, 6:8 (1970).

28. Morgan, C. R. and Lazarow, R.: Immunoassay of insulin: two antibody system. Diabetes, I2: 115 (1963)

29. Muggeo, M., Moghetti, P., Businaro, V., Valerio, A., Sartore, P., and Faronato, P. P.: Prednisone affects insulin binding to human erythrocytes independently of changes in mean cell age. Diabetologia, 21: 307 (Abstract) (1981).

30. Munck, A.: Glucocorticoid inhibition of glucose intake by peripheral tissues. Old and new evidence, molecular mechanism and physiological significance. Perspect. Biol. Med., 14: 265 (1971).

31. Olefsky, J. M., Johnson, J., Liu, F., Jen, P., and Reaven, G. M.: The effect of acute and chronic dexamethasone administration on insulin binding to isolated rat hepatocytes and adipocytes. Metabolism, 24: 517 (1975).

32. Olefsky, J. M.: Effects of Dexamethasone on insulin binding, glucose transport and glucose oxidation of isolated rat adipocytes, J. Clin. Invest., 56: 1499 (1975).

33. Owen, O. E. and Cahill, G. F.: Metabolic effects of exogenous glucocorticoids in fasted man. J. Clin. Invest., 52: 2596 (1973).

34. Perley, M. and Kipnis, D. M.: Effect of glucocorticoids on plasma insulin. N. Engl. J. Med., 271: 1237 (1966).

35. Plotz, C. M., Knowton, A. I., and Ragan, C.: Natural history of Cushing's syndrome. Am. J. Med., 13: 597 (1952).

36. Puppo, A. A., Wajchenberg, B. L., and Schneider, J.: Carbohydrate metabolism in hyperadrenocorticism. Diabetes, 15: 24 (1966).

37. Scatchard, G.: The attraction of proteins for small molecules and ions, Ann. N.Y. Acad. Sci., 51: 560 (1949).

38. Yasuda, K. and Kitabchi, A. E.: Decreased insulin binding of human erythrocytes after dexamethasone or prednisone ingestion. Diabetes, 29: 811 (1980).

39. The authors thank Anny Rainaud and Jacqueline Duch for the preparation of the manuscript and George Visciano for the illustrations.

40. Requests for reprints should be addressed to: Dr. B. Canivet, Department of Experimental Medicine, INSERM U 145, Faculté de Médecine, Chemin de Vallombrose, 06034 Nice Cédex, France.

41. This research was supported by a clinical research grant from Mission de la Recherche, Ministère de L'Education Nationale, Paris, France.

42. Received for publication August 17, 1982

43. Accepted for publication December 14, 1982 